\title{
FORECASTING OF SOCIO-ECONOMIC SECURITY INDICATORS BY MEANS OF EXPONENTIAL SMOOTHING
}

\author{
CShvaiba D., ORCID: 0000-0001-6783-9765, Ph.D., \\ Belarusian Trade Union of workers of chemical, mining and oil industries, \\ Belarusian national technical University, Minsk, Belarus, shvabia@tut.by
}

\section{ПРОГНОЗИРОВАНИЕ ПОКАЗАТЕЛЕЙ СОЦИАЛЬНО-ЭКОНОМИЧЕСКОЙ БЕЗОПАСНОСТИ СПОСОБОМ ЭКСПОНЕНЦИАЛЬНОГО СГЛАЖИВАНИЯ}

\author{
СШвайба Д. Н., ORCID: 0000-0001-6783-9765, канд. экон. наук, \\ Белорусский профсоюз работников химической, горной и нефтяной отраслей \\ промышленности, Белорусский национальный технический университет, \\ 2. Минск, Беларусь, shvabia@tut.by
}

Abstract. The method of exponential smoothing is widely used in the forecasting of financial and economic characteristics in different sectors of the economy, departments, etc. In the construction of a forecast model by exponential smoothing time series of characteristics of socio-economic security is smoothed with the support of a weighted moving average, in which the weights obey the exponential law. In this case, the following levels of the series are given significant values in comparison with the past, because they carry more important information to determine the predicted values at the level of socio-economic security characteristics.

Аннотащия. Способ экспоненциального сглаживания обширно используется при прогнозировании финансово-экономических характеристик в разных секторах экономики хозяйства, ведомствах и т.д. При построении прогнозной модели способом экспоненциального сглаживания временной ряд характеристик социально-экономической безопасности сглаживается с поддержкой взвешенной скользящей средней, в которой веса подчиняются экспоненциальному закону. В данном случае следующим уровням ряда придаются существенные значения в сравнении с прошлыми, т. к. они несут более важную информацию для определения прогнозируемых значений на уровне характеристик социально-экономической безопасности.

Keywords: socio-economic security, government, society, enterprise, employee, threat, security, interests, economics, analysis, system.

Ключевые слова: социально-экономическая защищенность, государство, общество, предприятие, работник, угроза, защищенность, интересы, экономика, анализ, система.

The method of exponential smoothing is widely used in forecasting financial and economic characteristics in different sectors of the economy, departments, etc. [1,2].

When constructing a predictive model by exponential smoothing, the time series of socioeconomic security characteristics is smoothed with the support of a weighted moving average, in which the weights obey the exponential law. In this case, the following levels of the series are given significant values in comparison with the past, since they carry more important information to determine the predicted values at the level of socio-economic security characteristics [3, p.81]. 
The predictive model constructed by the exponential smoothing method contains the following form:

$$
Y_{t+l}=\varphi(t)+\sigma_{t+l}
$$

where: $\varphi(t)$ - the deterministic part;

$\sigma_{t+l^{-}}$the margin of error;

$t+l$ - forecast period.

When using the method of exponential smoothing, the deterministic segment (the most possible variant of the forecast) is specified by the predictive model, the forecast error characterizing the upper and lower limit of the predicted values is calculated by formulas.

Let there be a time series of characteristics of socio-economic security $Y_{t}(t=1,2, \ldots, n)$, which is possible to represent a polynomial of $p$-th degree.

$$
Y_{t}=a_{0}+a_{1} t+\frac{a_{2}}{2 !} t^{2}+\cdots+\frac{a_{p}}{p !} t^{p}+\delta t
$$

Forecast levels of socio-economic security in the time period $t+1(t=n)$ can be computed by decomposition in Taylor series:

$$
Y_{t+l}=Y_{t}^{(0)}+l Y_{t}^{(1)}+\frac{1}{2 !}^{2} Y_{t}^{(2)}+\cdots+\frac{1}{k !}^{k} Y_{t}^{(k)}+\frac{1}{p !}^{p} Y_{1}^{(p)}
$$

where $Y_{t}^{(k)}$ - $\mathrm{k}$-th derivative at the time point t. Any $\mathrm{K}$-th $(\mathrm{k}=0,1,2, \ldots, \mathrm{p})$ derivative is expressed by a combination of exponential means up to $(\mathrm{p}+1)$ order:

$$
Y_{t(y)}^{[k]}=\alpha S_{t(y)}^{[k-1]}+\beta S_{t-1(y)}^{[k]}
$$

where $\alpha$ - smoothing factor.

In the scientific literature to select values of $\alpha$ were proposed various approaches $[4$, p. $118 ; 5$, p. 92; 6, S. 78]. Thus, the best value of $\alpha$ is proposed to be found by comparing the variance of deviations of the actual values of the indicators of socio-economic security characteristics from the predicted ones formed by models constructed by the method of exponential smoothing using different smoothing characteristics. In this regard, the number of characteristics of socio-economic security are symbolically divided into a retrospective stage and a stage of pre-emption. According to the data of the pre-forecast period, models are formed and the forecast for the entire length of the 2nd part of the time series of socio-economic security characteristics is made. Following this, the differences between the actual values of socio-economic security characteristics and the forecast and variance of these deviations are revealed. The smallest variance characterizes the suitable variant at which it is obtained and is used for subsequent calculations.

The main defects of the approach are labour costs and the need for a long time series of socioeconomic security statistics. 
In practical calculations, as a rule, a method is used to show the length of the smoothing interval with values that are calculated by empirical formulas:

$$
\alpha=\frac{2}{m+1}, \beta=1-\alpha
$$

where: $\mathrm{m}$ - smoothing time (shown with the periodization of forecasting, specific cyclic characteristics of socio-economic security, etc.))

Based on the recurrent formula 4. you can represent an exponential mean expression of any order for expression 3 .

$$
\begin{gathered}
S_{t(y)}^{[1]}=\alpha Y_{t(y)}+\beta S_{t-1(y)}^{[1]}, \\
S_{t(y)}^{[2]}=\alpha S_{t(y)}^{[1]}+\beta S_{t-1(y)}^{[2]} \\
S_{t(y)}^{[k]}=\alpha S_{t(y)}^{[k-1]}+\beta S_{t-1(y)}^{[k]} \\
S_{t(y)}^{[n]}=\alpha S_{t(y)}^{[n-1]}+\beta S_{t-1(y)}^{[n]}
\end{gathered}
$$

Using exponential averages, it is possible to obtain a system of equations that provide an opportunity to qualify the characteristics of predictive models of a linear and quadratic form used in the practice of forecasting the characteristics of socio-economic security.

Let us form a predictive model of the linear form by exponential smoothing. The predictive model of the linear form by means of exponential smoothing is created according to the parameters of table 1 . for a smoothing period of 4 years $(m=4)$.

Then:

$$
\alpha=\frac{2}{4+1}=0,4, \beta=1-\alpha=0,6
$$

Using the system of normal equations the trend parameters are revealed:

$$
Y=1360,0+124,855 t \text { и } \sigma_{t}=148,641 \text {. }
$$

Then the initial conditions are calculated $S_{0(y)}^{[1]}$ and $S_{0(y)}^{[2]}$

Table 1.

PRIMARY DATA AND INTERMEDIATE CALCULATIONS TO CALCULATE THE PARAMETERS OF THE LINEAR MODEL BY THE METHOD OF EXPONENTIAL SMOOTHING

\begin{tabular}{ccccccc}
\hline Year & $Y$ & $S_{0(y)}^{[1]}$ & $S_{0(y)}^{[2]}$ & $a_{0}$ & $a_{1}$ & $\hat{Y}$ \\
\hline $\mathrm{t}-9$ & 1637 & & & & & \\
$\mathrm{t}-8$ & 1683 & 1358,430 & 1134,634 & 1582,227 & 149,198 & 1731,425 \\
$\mathrm{t}-7$ & 1750 & 1488,258 & 1276,083 & 1700,433 & 141,449 & 1841,882 \\
$\mathrm{t}-6$ & 1796 & 1592,955 & 1402,083 & 1783,078 & 126,748 & 2909,826 \\
$\mathrm{t}-5$ & 1876 & 1674,173 & 1511,368 & 1836,977 & 108,536 & 1945,513 \\
$\mathrm{t}-4$ & 1983 & 1754,904 & 1608,782 & 1901,025 & 97,414 & 1998,439 \\
$\mathrm{t}-3$ & 2089 & 1846,142 & 1703,726 & 1988,558 & 94,943 & 2083,501 \\
$\mathrm{t}-2$ & 2225 & 1943,285 & 1799,550 & 2087,020 & 95,824 & 2182,844 \\
$\mathrm{t}-1$ & 2549 & 2055,971 & 1902,118 & 2209,824 & 102,568 & 2312,392 \\
$\mathrm{t}$ & 2879 & 2253,183 & 2042,544 & 2463,821 & 140,425 & 2604,246 \\
$\mathrm{t}+1$ & & 2503,509 & 2226,930 & 2780,089 & 184,386 & 2964,475 \\
\hline Source
\end{tabular}

Source: elaboration of author 


$$
\begin{gathered}
S_{0(y)}^{[1]}=a_{0(t)}-\frac{\beta}{\alpha} \alpha_{l(t)}=1360.000-\frac{0,6}{0,4} 124,855=1172,717 \\
S_{0(y)}^{[2]}=\alpha_{0(t)}-\frac{2 \beta}{\alpha} \alpha_{1(t)}=1360.000-\frac{2 \times 0,6}{0,4} 124,855=985,435
\end{gathered}
$$

In that case $S_{0(y)}^{[1]}$ and $S_{0(y)}^{[2]}$ respectively are equal:

$$
\begin{gathered}
S_{0(y)}^{[1]}=\alpha Y_{t-1}+\beta S_{0(y)}^{[1]}=0,4 \times 1637+0,6 \times 1172,717=1358,435 \\
S_{0(y)}^{[2]}=\alpha S_{t(y)}^{[1]}+\beta S_{t(y)}^{[2]}=0,4 \times 1358,430+0,6 \times 985,435=1134,633
\end{gathered}
$$

On this basis

$$
\begin{gathered}
\alpha_{0}=2 S_{t(y)}^{[1]}-S_{t(y)}^{[2]}=2 \times 1358,430-1134,633=1582,277 \\
\alpha_{1}=\frac{\alpha}{\beta} \times\left(S_{t(y)}^{[1]}-S_{t(y)}^{[2]}\right)=\frac{0,4}{0,6} \times(1358,430-1134,633)=149,198 \\
S_{t(y)}^{[1]}=\alpha Y_{t(y)}+\beta S_{t-1(y)}^{[1]}=0,4 \times 1683,0+0,6 \times 1358,430=1488,258 \\
2 S_{t(y)}^{[2]}=\alpha S_{t(y)}^{[1]}+\beta S_{t-1(y)}^{[2]}=0,4 \times 1488,258+0,6 \times 1134,633=1276,082
\end{gathered}
$$

Intermediate data are included in the table (table 1.). form:

The predictive model of exponential smoothing of the linear form for $t+1$ year will have the

where: $\mathrm{t}=1$ for $\mathrm{t}+1$

$$
Y_{t+l}=2780,089+184,386 t
$$

Forecasted value $\widehat{\mathrm{Y}_{t+l}}$ are calculated by putting the indicator $\mathrm{t}$ of the year in the forecast model:

$$
\begin{aligned}
& \widehat{Y_{t+l}}=2780,089+184,386 \times 1=2964,475 \\
& \cdots \cdots \cdots \cdots \cdots \cdots \cdots \cdots \cdots \cdots \cdots \cdots \cdots \cdots \cdots \cdots \cdots \cdots \cdots \cdots \cdots \cdots \cdots \cdots \cdots \cdots \cdots \cdots \\
& \widehat{Y_{t+l}}=2780,089+184,386 \times 1=2964,475
\end{aligned}
$$

The forecast error is calculated by the formula:

$$
\sigma_{y(t+l)}= \pm \sigma_{\varepsilon t} \sqrt{\frac{\alpha}{(2-\alpha)^{2}}\left[1+4(1-\alpha)+5(1-\alpha)^{2}+2 \alpha(4-3 \alpha) e+2 \alpha^{2} e^{2}\right]}
$$

where: $\sigma_{\varepsilon t}$ - the mean square error calculated for deviations from the linear trend formed by the least squares method.

$$
\begin{gathered}
\sigma_{y(t+1)}= \pm 148,641 \times \\
\times \sqrt{\frac{0,4}{(2-0,4)^{3}}\left[1+4(1-0,4)+5(1-0,4)^{2}+2 \times 0,4(4-3 \times 0,4) \times 1+2 \times 0,4^{2} \times 1^{2}\right]} \\
= \pm 129,396 \quad \sigma_{y(t+5)}= \pm 148,641 \times \\
\times \sqrt{\frac{0,4}{(2-0,4)^{3}}\left[1+4(1-0,4)+5(1-0,4)^{2}+2 \times 0,4(4-3 \times 0,4) \times 1+2 \times 0,4^{2} \times 1^{2}\right]} \\
= \pm 229,448
\end{gathered}
$$


Forecast data of socio-economic security indicators are summarized in Table 2.

FORECASTED VALUE $\hat{Y}$ and $\widehat{Y} \pm \sigma_{y}$ in $\mathrm{t}+1-\mathrm{t}+5$ years

Table 2.

\begin{tabular}{ccccc}
\hline Год & $Y_{t+e}$ & $\sigma_{y(t+1)}$ & \multicolumn{2}{c}{ Lower and upper boundaries } \\
\cline { 3 - 5 } & & & $\widehat{Y_{t+e}}-\sigma_{y(t+1)}$ & $\widehat{Y_{t+e}}+\sigma_{y(t+1)}$ \\
\hline $\mathrm{t}+1$ & 2964,475 & 129,396 & 2835,079 & 3093,871 \\
$\mathrm{t}+2$ & 3148,861 & 153,778 & 2995,083 & 3302,639 \\
$\mathrm{t}+3$ & 3333,247 & 178,698 & 3154,549 & 3511,945 \\
$\mathrm{t}+4$ & 3517,633 & 203,959 & 3313,674 & 3721,592 \\
$\mathrm{t}+5$ & 3702,019 & 229,448 & 3472,571 & 3931,467 \\
\hline
\end{tabular}

Source: elaboration of author

By changing the value of the smoothing period using the exponential smoothing method, it is possible to create a number of linear predictive models. Thus, linear models of exponential smoothing formed at the smoothing period of 3,4,5 and 6 years have the following form:

$$
\begin{aligned}
& \widehat{Y_{(3)}}=2822,830+219,1524 t \\
& \widehat{Y_{(4)}}=2780,089+184,3860 t \\
& \widehat{Y_{(5)}}=2743,712+163,3480 t \\
& \widehat{Y_{(6)}}=2715,079+150,5091 t
\end{aligned}
$$

where $t_{1}$ for $\mathrm{t}+1$ year is 1 .

The choice of a specific forecast model can be made by comparing the deviations of the calculated levels of socio-economic security characteristics from the actual ones in the pre-forecast period. $\widehat{Y}_{\mathrm{j}}>Y_{j}-$ the minus sign, $\widehat{Y}_{\mathrm{j}}<\mathrm{Y}_{\mathrm{j}}$ - plus sign (Table 3 ).

Table 3.

COMPARATIVE DEVIATION VALUES $\widehat{Y}_{\mathrm{J}}$ FROM $\mathrm{Y}_{\mathrm{J}}$ IN THE CASE OF LINEAR EXPONENTIAL SMOOTHING MODELS, $\%$

\begin{tabular}{ccccc}
\hline Year & \multicolumn{4}{c}{ The smoothing period } \\
\cline { 2 - 5 } & $m=3$ & $m=4$ & $m=5$ & $m=6$ \\
\hline $\mathrm{t}-8$ & $-4,63$ & $-2,87$ & $-1,67$ & $-0,81$ \\
$\mathrm{t}-7$ & $-5,48$ & $-5,25$ & $-4,81$ & $-4,35$ \\
$\mathrm{t}-6$ & $-5,41$ & $-6,34$ & $-6,72$ & $-5,84$ \\
$\mathrm{t}-5$ & $-2,09$ & $-3,71$ & $-4,77$ & $-5,47$ \\
$\mathrm{t}-4$ & $+0,61$ & $-0,78$ & $-1,95$ & $-2,87$ \\
$\mathrm{t}-3$ & $+1,00$ & $+0,26$ & $-0,61$ & $-1,43$ \\
$\mathrm{t}-2$ & $+2,15$ & $+1,89$ & $+1,35$ & $+0,73$ \\
$\mathrm{t}-1$ & $+9,05$ & $+9,28$ & $+9,17$ & $+8,89$ \\
$\mathrm{t}$ & $+7,80$ & $+8,61$ & $+10,57$ & $+11,16$ \\
\hline
\end{tabular}

Source: elaboration of author

The minimum deviations of the calculated values of the socio-economic security characteristics from the actual ones in the last year of the pre-forecast period are obtained by a linear model, a constant method of exponential smoothing at the smoothing period of 3 years (Table $3)$. 
We construct a predictive model of the quadratic form by exponential smoothing. To form a predictive model of a quadratic form by means of exponential smoothing, we apply the data of table 1. and smoothing period of 3 years $(\alpha=0,5 ; \beta=0,5)$.

Primary conditions $S_{0(y)}^{[1]}, S_{0(y)}^{[2]}$ and $S_{0(y)}^{[3]}$ equal.

$$
\begin{gathered}
S_{0(y)}^{[1]}=a_{0(t)}-\frac{\beta}{\alpha} \alpha_{1(t)}+\frac{\beta(2-\alpha)}{\alpha} \alpha_{2(t)}=1734,495-\frac{0,5}{0,5} \times(-62,395)+ \\
+\left(\frac{0,5(2 \times 0,5)}{0,5} 17,023\right)=1847,959 \\
S_{0(y)}^{[2]}=a_{0(t)}-\frac{2 \beta}{\alpha} \alpha_{1(t)}+\frac{2 \beta(3-2 \alpha)}{\alpha} \alpha_{2(t)}=1734,495-2 \frac{0,5}{0,5} \times(-62,395)+ \\
+\left(\frac{3-2 \times 0,5}{0,5} 17,023\right)=1995,468 \\
S_{0(y)}^{[3]}=a_{0(t)}-\frac{3 \beta}{\alpha} \alpha_{1(t)}+\frac{3 \beta(4-3 \alpha)}{\alpha^{2}} \alpha_{2(t)}=1734,495-3 \frac{0,5}{0,5} \times(-62,395)+ \\
+\left(\frac{3 \times 0,5(4-3 \times 0,5)}{0,5^{2}} 17,023\right)=2177,023
\end{gathered}
$$

where $a_{0(t)}, a_{1(t)}, a_{2(t)}$ - indicators of trends of models of the quadratic form calculated by the solution of systemthe of the normal equations - for the simulated number of levels of characteristics of social and economic safety the model will have the form:

$$
\widehat{Y}=1734.495-62.395 t+17.023 t^{2}\left(\text { at } t_{1} \text { for } t+1 \text { years }=11\right)
$$

Calculated $S_{t(y)}^{[1]}, S_{t(y)}^{[2]}$ and $S_{t(y)}^{[3]}$

$$
\begin{gathered}
S_{t(y)}^{[1]}=\alpha Y_{t-1}+\beta S_{t-1(y)}^{[1]}=0,5 \times 1637+0,4 \times 1847,959=1742,479 \\
S_{t(y)}^{[2]}=\alpha S_{t(y)}^{[1]}+\beta S_{t-1(y)}^{[2]}=0,5 \times 1742,479+0,5 \times 1995,461868,973 \\
S_{t(y)}^{[3]}=\alpha S_{t(y)}^{[2]}+\beta S_{t-1(y)}^{[3]}=0,5 \times 1868,973+0,5 \times 2177,023=2022,998
\end{gathered}
$$

Model parameter $a_{0}, a_{1}, a_{2}$ equal:

$$
\begin{gathered}
a_{0}=3\left(S_{t(y)}^{[1]}-S_{t(y)}^{[2]}\right)+S_{t(y)}^{[3]}=3(1742,479-1868,973)+2022,998=1643,516 \\
\quad a_{1}=\frac{\alpha}{2(1-\alpha)^{2}} \\
\quad \times[(6-5 \times 0.5) \times 1742,479-2(5-4 \times 0,5) \times 1868,973+(4-3 \times 0,5) \times \\
\times 2022,988]=57659 \\
\quad a_{2}=\frac{\alpha^{2}}{(1-\alpha)^{2}} \times S_{t(y)}^{[1]}-2 S_{t(y)}^{[2]}+S_{t(y)}^{[3]} \\
=\frac{0,52}{2(1-0,5)^{2}} \times(1742,479-2 \times 1868,973+2022,998)=27,530
\end{gathered}
$$

In that case $\widehat{Y}_{t-8}$ equal 1599,$611 ; \mathrm{Y}_{\mathrm{j}}-\widehat{\mathrm{Y}}_{\mathrm{j}}$ for $\mathrm{t}-8$ years equal $83,389\left(\widehat{\mathrm{Y}}_{\mathrm{j}}-\right.$ calculated for $\mathrm{t}-8 / \mathrm{t}$ years).

Then, the integration calculation is repeated for $S_{t(y)}^{[1]}, S_{t(y)}^{[2]}$ and $S_{t(y)}^{[3]} ; a_{0}, a_{1}, a_{2} ; \widehat{\mathrm{Y}}_{\mathrm{j}}, \mathrm{Y}_{\mathrm{j}}-\widehat{\mathrm{Y}}_{\mathrm{j}}$. Intermediate calculations are formed in table 4. 
Forecasted value $\widehat{\mathrm{Y}_{\mathrm{t}-\mathrm{e}}}$ are calculated by the formula:

$$
\hat{Y}_{t-1}=a_{0}+a_{1 t}+\frac{a_{2}}{2} \mathrm{t}^{2}
$$

where: $t_{1}$ for $\mathrm{t}+1$ years equal 1 ,

$$
\begin{aligned}
& \hat{Y}_{t+1}=2870,749+342,341 \times 1+\frac{1}{2} \times 50,579 \times 1^{2}=3238,379 \\
& \widehat{Y}_{t+5}=2870,749+342,341 \times 5+\frac{1}{2} \times 50,579 \times 5^{2}=3238,379
\end{aligned}
$$

The forecast error is found by the formula:

$$
\sigma_{y(t+1)}= \pm \sigma_{\varepsilon t} \sqrt{2 \alpha+3 \alpha^{2}+3 \alpha^{2} t^{2}}
$$

where $\sigma_{\varepsilon t}$ - the standard deviation of the actual equations of characteristics of social and economic security from the calculated, calculated by the trend model of the quadratic form, and equal $\pm 58,2526$.

Then:

$$
\begin{gathered}
\sigma_{t+1}= \pm 5,2556 \sqrt{2 \times 0,5+3 \times 0,5^{2}+3 \times 0,5^{3} \times 1}= \pm 84,917 \\
\cdots \quad \cdots \\
\sigma_{t+5}= \pm 5,2556 \sqrt{2 \times 0,5+3 \times 0,5^{2}+3 \times 0,5^{3} \times 5^{2}}= \pm 194,297
\end{gathered}
$$

Indicators $\hat{Y}_{t+1}, \hat{Y}_{t+1} \sigma_{y(t+1)}, \sigma_{y(t+1)}$ are summarized in table 4 . The models of the quadratic form formed by the method of exponential smoothing at the period of smoothing in 3,4,5 and 6 years will have the form:

$$
\begin{aligned}
& \hat{Y}_{(3)}=2870,749+342,341 t+1 / 2 \times 50,579 t^{2} \\
& \hat{Y}_{(4)}=2857,399+316,279 t+1 / 2 \times 41,703 t^{2} \\
& \hat{Y}_{(5)}=2845,564+300,589 t+1 / 2 \times 57,714 t^{2} \\
& \hat{Y}_{(6)}=2836,365+219,699 t+1 / 2 \times 35,906 t^{2}
\end{aligned}
$$

Table 4

PRIMARY DATA AND INTERMEDIATE CALCULATIONS FOR CALCULATING THE PARAMETERS OF THE PREDICTIVE MODEL OF EXPONENTIAL SMOOTHING OF THE QUADRATIC FORM

\begin{tabular}{cccccccc}
\hline Year & $Y$ & $S_{t(y)}^{[1]}$ & $S_{t(y)}^{[2]}$ & $S_{t(y)}^{[3]}$ & $a_{0}$ & $a_{1}$ & $a_{2}$ \\
\hline $\mathrm{t}-9$ & 1637 & & & & & & \\
$\mathrm{t}-8$ & 1750 & 1742,479 & 1868,973 & 2022,998 & 1643,515 & $-57,659$ & 27,530 \\
$\mathrm{t}-7$ & 1750 & 1712,739 & 1790,856 & 1906,927 & 1672,576 & 16,767 & 37,954 \\
$\mathrm{t}-6$ & 1796 & 1731,369 & 1761,113 & 1834,020 & 1744,790 & 78,165 & 43,164 \\
$\mathrm{t}-5$ & 1876 & 1763,684 & 1762,399 & 1798,209 & 1802,067 & 94,027 & 37,096 \\
$\mathrm{t}-4$ & 1983 & 1819,842 & 1791,120 & 1794,665 & 1880,830 & 109,387 & 32,266 \\
$\mathrm{t}-3$ & 2089 & 1901,421 & 1846,271 & 1820,468 & 1985,918 & 128,518 & 29,347 \\
$\mathrm{t}-2$ & 2225 & 1995,210 & 1920,740 & 1870,604 & 2094,013 & 135,303 & 24,333 \\
$\mathrm{t}-1$ & 2549 & 2110,105 & 2015,423 & 1943,013 & 2227,060 & 150,365 & 22,273 \\
$\mathrm{t}$ & 2879 & 2329,552 & 2172,487 & 2057,750 & 2528,945 & 262,884 & 42,328 \\
$\mathrm{t}+1$ & & 2604,276 & 2388,382 & 2223,066 & 2870,749 & 342,341 & 50,579 \\
\hline
\end{tabular}

Source: elaboration of author 
Table 5 .

FORECAST DATA $\hat{Y}_{t+l}, \sigma_{y(t+l)}$ and $\hat{Y}_{t+l} \pm \sigma_{y(t+l)}$

\begin{tabular}{clrrr}
\hline Year & $\hat{Y}_{t+e}$ & $\sigma_{y(t+e)}$ & \multicolumn{2}{c}{ Lower and upper boundaries } \\
\cline { 3 - 5 } & & & $\hat{Y}_{t+e}-\sigma_{y(t+e)}$ & $\hat{Y}_{t+e}+\sigma_{y(t-e)}$ \\
\hline $\mathrm{t}+1$ & 3238,379 & 84,917 & 3153,462 & 3323,296 \\
$\mathrm{t}+2$ & 3635,589 & 105,016 & 3551,573 & 3761,605 \\
$\mathrm{t}+3$ & 4125,377 & 131,875 & 3993,502 & 4257,252 \\
$\mathrm{t}+4$ & 4644,745 & 162,168 & 4482,577 & 4806,913 \\
$\mathrm{t}+5$ & 5214,688 & 194,297 & 5020,391 & 5408,985 \\
\hline
\end{tabular}

Source: elaboration of author

Deviations of the actual levels of socio-economic security characteristics from the calculated ones calculated by quadratic models of exponential smoothing are given in table 6. ( $\widehat{Y}_{\mathrm{j}}>\mathrm{Y}_{\mathrm{j}}-$ the minus sign, $\widehat{Y}_{\mathrm{j}}<\mathrm{Y}_{\mathrm{j}}$ - plus sign).

Table 6 .

COMPARATIVE INDICATORS OF DEVIATIONS $\widehat{Y}_{\mathrm{J}}$ FROM $\mathrm{Y}_{\mathrm{J}}$ WHEN USING LINEAR MODELS OF EXPONENTIAL SMOOTHING, \%

\begin{tabular}{ccccc}
\hline Year & \multicolumn{4}{c}{ The smoothing period } \\
\cline { 2 - 5 } & $m=3$ & $m=4$ & $m=5$ & $+3,41$ \\
\hline $\mathrm{t}-8$ & $+4,95$ & $+4,03$ & $+3,96$ \\
$\mathrm{t}-7$ & $+2,38$ & $+3,18$ & $-0,59$ & $+3,67$ \\
$\mathrm{t}-6$ & $-2,70$ & $-1,45$ & $-1,67$ & $+0,01$ \\
$\mathrm{t}-5$ & $-2,05$ & $-2,00$ & $-1,88$ & $-1,31$ \\
$\mathrm{t}-4$ & $-1,18$ & $-1,73$ & $-3,06$ & $-1,85$ \\
$\mathrm{t}-3$ & $-1,92$ & $-2,63$ & $-2,54$ & $-3,30$ \\
$\mathrm{t}-2$ & $-0,74$ & $-1,75$ & $+4,68$ & $+3,12$ \\
$\mathrm{t}-1$ & $+6,28$ & $+5,49$ & $+3,92$ & $+3,97$ \\
$\mathrm{t}$ & $+2,29$ & $+3,45$ & & $+4,04$ \\
\hline
\end{tabular}

Source: elaboration of author

Thus, the minimum deviation of the actual values of the socio-economic security characteristics from the calculated ones in the pre-forecast period was obtained by applying the quadratic model of exponential smoothing built at the smoothing period of 3 years. The revealed results make sense to apply in the analysis of socio-economic security at the level of the country, region and economic entity to develop certain measures to counter the detected threats.

\section{References:}

1. Kil'dishev, G. S., \& Frenkel', A. A. (1973). Analiz vremennykh ryadov i prognozirovanie. Moscow: Statistika. 103.

2. Darmoyan, P. A., \& Kuchevskii, N. G. (1975). Metody prognozirovaniya passazhirskikh perevozok. Minsk: Nauka i tekhnika. 85.

3. Ak'yulov, R. I. (2015). Problemy i perspektivy monitoringa i otsenki sotsial'noekonomichesko bezopasnosti rossiiskikh regionov. Voprosy upravleniya, (1). 78-86.

4. Borzykh, L. A. (2016). Organizatsionno-ekonomicheskii instrumentarii obespecheniya ekonomicheskoi bezopasnosti v sotsial'noi sfere: dis. ... kand. ekon. nauk. St. Petersburg, 206. 
5. Medvedev, P. V. (2015). Otsenka ekologicheskoi i sotsial'noi effektivnosti infrastrukturnykh proektov $\mathrm{v}$ obespechenii ekonomicheskoi bezopasnosti: dis. ... kand. ekon. nauk. Moscow, 180.

6. Orekhov, A. M. (2012). Sotsial'nye nauki, intelligentsiya i spravedlivost' v fokuse sotsial'no-filosofskikh i filosofsko-ekonomicheskikh issledovanii. Korolev: Kosmos, 143.

7. Shvaiba, D. (2019). Dynamic regression models of forecasting indicators of social and economic security. Bulletin of Science and Practice, 5(1), 249-257.

8. Shvaiba, D. (2018). Socio-economic security of the hierarchical system. Bulletin of Science and Practice, 4(6), 248-254.

\section{Список литературы:}

1. Кильдишев Г. С., Френкель А. А. Анализ временных рядов и прогнозирование. М.: Статистика. 1973. $103 \mathrm{c.}$

2. Дармоян П. А., Кучевский Н. Г. Методы прогнозирования пассажирских перевозок. Минск: Наука и техника. 1975. 85 с.

3. Акьюлов Р. И. Проблемы и перспективы мониторинга и оценки социальноэкономическо безопасности российских регионов // Вопросы управления. 2015. №1. С. 7886.

4. Борзых Л. А. Организационно-экономический инструментарий обеспечения экономической безопасности в социальной сфере: дис. ... канд. экон. наук. СПб., 2016. 206 с.

5. Медведев П. В. Оценка экологической и социальной эффективности инфраструктурных проектов в обеспечении экономической безопасности: дис. ... канд. экон. наук. М., 2015. 180 с.

6. Орехов А. М. Социальные науки, интеллигенция и справедливость в фокусе социально-философских и философско-экономических исследований. Королев: Космос, 2012. $143 \mathrm{c}$.

7. Shvaiba D. Dynamic regression models of forecasting indicators of social and economic security // Бюллетень науки и практики. 2019. Т. 5. №1. С. 249-257.

8. Shvaiba, D. Socio-economic security of the hierarchical system // Бюллетень науки и практики. 2018. Т. 4. №6. С. 248-254.

Работа поступила

в редакияию 17.02.2019 2.
Принята к публикациии

21.02.2019 2.

Cite as (APA):

Shvaiba, D. (2019). Forecasting of socio-economic security indicators by means of exponential smoothing. Bulletin of Science and Practice, 5(3), 241-249. https://doi.org/10.33619/2414-2948/40/30.

Ссылка для ичитирования:

Shvaiba D. Forecasting of socio-economic security indicators by means of exponential smoothing // Бюллетень науки и практики. 2019. Т. 5. №3. С. 241-249. https://doi.org/10.33619/2414-2948/40/30. 